\title{
CONTENT AND TYPES OF PROCEDURAL DISCRETION OF ADMINISTRATIVE COURT OF CASSATION OF THE SUPREME COURT: PRELIMINARY THOUGHTS ${ }^{1}$
}

\section{Bevzenko V. M.}

\section{INTRODUCTION}

Administrative Court of Cassation of the Supreme Court (hereinafter referred to as Administrative Court of Cassation, the Court) as well as local administrative courts and administrative courts of appeal based on the Code of Administrative Legal Proceedings of Ukraine (hereinafter referred to as the CAP of Ukraine) have the right to approve judicial decisions (court determinations, resolutions, orders) (Art. 241 of the Code of Administrative Legal Proceedings of Ukraine), that according to this Court are the most suitable for actual circumstances of the administrative case, procedural resolutions, actions, inaction of Legal Proceedings participants, provisions of procedural and substantive legislation ${ }^{2}$.

In fact, when the judge of Administrative Court of Cassation in accordance with Art. 31 of the Code of Administrative Legal Proceedings of Ukraine receives a statement of claim, a statement, a petition, a cassation appeal, a revocation, an objection to the applications filed or petitions (Articles 160, 162, 163, 164, 166, 330, 334, 338, 344 of the CAP of Ukraine), he faces not an easy choice as to which procedural decision he should approve. The necessity to make a reasonable choice is objectively inherent in the whole process of considering and resolving an administrative case and all the procedural actions associated with it.

A judge is not just before a choice, having the opportunity to choose one solution from several. The judicial decision is always preceded by the complex, judge's continuous research activity, involving a critical evaluation of actual circumstances of the case, procedural decisions, actions, inaction of the participants in judicial procedure, the local administrative court, the administrative court of appeal, in gathering evidence, comparing them with the actual circumstances of the case and,

\footnotetext{
${ }^{1}$ Стаття підготовлена з урахуванням національного законодавства станом на 1.11 .2018 р.

${ }^{2}$ Кодекс адміністративного судочинства України: Закон України від 06.07.05 p. № 2747-IV (в редакції Закону України від 03.10.17 р. № 2147-VIII). Відомості Верховної Ради України. 2017. № 48. С. 5.
} 
finally, in drawing conclusions that are as much as possible correspond to previously collected information.

Many factors influence the choice of a judge of the Administrative Court of Cassation, such as: actual circumstances of the case, the content of disputed legal relations and their subjects, time of a dispute, legal regulation and the validity of law norms at the time of relations occurrence, judicial practice, and the practice of the European Court of Human Rights.

Almost the first task for a judge of the Administrative Court of Cassation, who is getting familiar with administrative documents, is to determine the limits and scope of actual information and circumstances, to search and select relevant legislation governing the disputed legal relations, and to apply the proper administrative procedural norm. Finally, such analytical activity involves the mandatory formation of accurate, justified, relevant and unambiguous conclusions concerning circumstances, the essence of an administrative case and proper procedural actions of the Court.

The Administrative Court of Cassation has a significant amount of procedural powers for the consideration and resolution of administrative cases stipulated by the current Code of Administrative Legal Proceedings of Ukraine. Accordingly, the court decisions of this Court are numerous and diverse, since they are a form and, consequently, a consequence of the exercise of their powers.

Taking into account the number of court decisions made by the Administrative Court of Cassation, and also in view of the necessity to ensure the proper protection of rights, freedoms, and interests of physical persons (legal entities), there is an objective need for the development and implementation of a uniform algorithm (sequence) for the formation of a justified and correct conclusions by the Court as a result of consideration and resolution of an administrative case, the procedural actions performed.

It seems that the development and implementation of the algorithm (sequence) of justified and correct conclusion formation by the Court depends, in turn, on justification for the implementation of procedural discretion by the Administrative Court of Cassation during the consideration and resolution of the administrative case, performing procedural actions by judicial process participants. Although discretionary 
powers are necessary to perform the full range of power functions in modern complex societies, the powers mentioned should not be exercised in an arbitrary manner, since this will lay the foundations for the adoption of substantially unfair, unjustified, unreasonable or oppressive decisions that are incompatible with the notion of the supremacy of $\operatorname{law}^{3}$.

\section{Analysis of the Latest Studies and Publications}

The subject of procedural discretion (judicial discretion) is not entirely new for the national science of administrative law and procedure. At one time, its history was already enriched with theoretical and applied achievements and progressive examples of norm-making. The principles of national administrative judicial procedure, including discretion, were developed at the beginning of the last century by the representatives of legal science, as well as state officials and lawmakers. The Institution of procedural discretion was implemented in the norms of the draft law on courts in administrative cases of the Ukrainian People's Republic of 1932. For example, Article 80 of the Draft Law on Courts in Administrative cases stipulated that the court could increase the penalty at its own discretion; in administrative cases of non-property nature, the court, at its discretion, was allowed to establish the price of claim at the time of the sentence approval ${ }^{4}$.

Procedural discretion is one of the institutions of administrative procedural law of states with advanced science, legislation and practice of administrative legal proceedings 5 .

The institution of administrative proceedings, - Yu.L. Paneyko wrote,- does not create a goal for itself, but is only a practical thing that should provide units [subjects] with the legal functioning of administrative apparatus. Judicial and administrative supervision should

\footnotetext{
${ }^{3}$ Сергій Головатий, 'Верховенство права (правовладдя): як його тлумачить Венеційська Комісія'. Верховенство права: доповідь, схвалена Венеційською Комісією на 86-му пленарному засіданні (Венеція 25-26 березня 2011 року) (2011) 10 Право України 168-184; Report on the Rule of Law. Adopted by the Venice Commission at its 86th plenary session (Venice, 25-26 March 2001) on the basis of comments by Mr Pieter van Dijk (Member, Netherlands), Ms Gret Haller (Member, Switzerland), Mr Jeffrey Jowell (Member, United Kingdom), Mr Kaarlo Tuori (Member, Finland). Study No. 512/2009. CDL\#AD(2011)003rev. Or. Engl.

${ }^{4}$ Гриценко I та інші (уклад) Адміністративне право і процес УНР в екзилі: невідома правнича спадщина України. за заг. ред. I Гриценка. (Дакор 2015) 363, 373, 466, 476, 496.

${ }^{5}$ Friedhelm Hufen Verwaltungsprozessrecht. 7., vollig neu bearbeitete Auflage. Verlag C.H. (Beck 2008) 101-104, 395-400, 448-450, 455-463, 472-476, 488-500, 604-605, 612-613.
} 
become a measure of administrative justice and the highest authority of the means of public administration supervision ${ }^{6}$.

Noting that administrative legal proceedings should be not only a supervisor, but also a regulator of the whole administration, the scholar proposed six of its postulates ${ }^{7}$.

1. Administrative court is obliged to examine not only legitimacy (legality), but also reasonability ${ }^{8}$ of public authority activity. Conducting inspections of administrative acts by administrative courts adopted on the basis of administrative discretion of public authorities provides a reasonable restriction to the minimum of discretionary power of administrative bodies.

2. The administrative court is obliged to cover the objective order of the state by a comprehensive supervision, and not to protect only the public-subjective rights. In accordance with this postulate, a judicial and administrative complaint must serve as "actio popularis" for every citizen; the supervision over the activities of administrative authorities is established by submission of such complaint.

3. The administrative court can not be limited by cancellation of administrative acts only - it is obliged to carry out merit inspection [of these acts] ${ }^{9}$.

4. The administrative court is also obliged to examine punitiveadministrative cases, this way focusing the completeness of justice in the field of public administration.

5. The administrative court is obliged to carry out actively its procedural powers in case of so called power silence ${ }^{10}$, namely, nonsolving the administrative case in a certain period of time ${ }^{11}$.

6 . The structure of administrative judicial procedure should be based on the principle of multi-levelness ${ }^{12}$, and in specific cases - on separation from certain branches of administration as well.

We believe that distinguishing the postulates of administrative judicial procedure mentioned, Yu.L. Paneyko not only (and not so much)

\footnotetext{
${ }^{6}$ Бевзенко В та інші (уклад) Наука адміністрації й адміністративного права. Загальна частина (за викладами професора Юрія Панейка) ( Дакор 2016) 379, 384, 385.

${ }^{7}$ Вимоги, які мають дотримуватися під час реалізації теорії адміністративного судочинства (прим. aвm.).

${ }^{8}$ Обгрунтованість (прим. авт.).

${ }^{9}$ Перевірка обгрунтованості адміністративного акту (прим. авт.).

${ }^{10}$ Бездіяльності (прим. авт.).

${ }^{11}$ Відрізку (прим. авт.).

${ }^{12}$ На принципі ієрархічності (прим. авт.).
} 
recognized the existence of discretion of the administrative court and thought about its peculiarities but in a way of justification of these postulates he recognized its limits and the grounds for administrative court discretion.

\section{Formation of Article Objectives}

The theoretical applied provisions which are of thorough attention are as follows: on what exactly the procedural discretion of the Administrative Court of Cassation may extend, what criteria of such discretion are $^{13}$ used. The emergence of the procedural discretion of administrative courts in general and the procedural discretion of the administrative court of cassation in particular is associated with the adoption in 2005 the Code of Administration Legal Proceedings of Ukraine. The legislative embodiment of the constitutional idea of protecting constitutional rights and freedoms of a person and a citizen (Art. 8, 55 of the Constitution of Ukraine) for the first time in the history of a new Ukrainian state has resulted in the consolidation of powers of administrative courts regarding the consideration of administrative jurisdiction cases, the procedure for appeal to administrative courts and implementation of administrative legal proceedings, and not only that ${ }^{14}$.

By the norms of the Code of Administrative Legal Proceedings of Ukraine, administrative courts are also vested with the right to choose a procedural decision. For example, the court of cassation instance according to the outcomes of cassation complaint consideration has the right (Art. 349 CAP of Ukraine) ${ }^{15}$ :

1) To leave the judge decisions of the first and/or appellate instance without changes, and a complaint - without satisfaction;

2) To revoke judicial decisions of the judges of the first and/or appellate instance in full or in part and to bring the case in full or in part to the new consideration, in particular according to jurisdiction established or for continuing consideration;

3) To revoke judicial decisions of the judges of the first and/or appellate instance in full or in part and to approve a new decision in the

\footnotetext{
${ }^{13}$ Критерії процесуального розсуду - обставини фактичного і нормативного змісту, які визначають зміст, види, «широту» такого розсуду.

${ }^{14}$ Кодекс адміністративного судочинства України: Закон України від 06.07.05 p. № 2747-IV (в редакції Закону України від 03.10.17 р. № 2147-VIII). Відомості Верховної Ради України. 2017. № 48. C. 5.

${ }^{15}$ Кодекс адміністративного судочинства України: Закон України від 06.07.05 p. № 2747-IV (в редакції Закону України від 03.10.17 р. № 2147-VIII). Відомості Верховної Ради України. 2017. № 48. С. 5.
} 
appropriate part or the change the decision not bringing the case to a new consideration;

4) To revoke a court resolution of the appellate instance in full or partially and to leave the court decision of the court of first instance in the appropriate part in force;

5) To revoke the court decisions of the court of the first and/or appellate instance in full or partially and to close a case or to leave a claim without discretion in the appropriate part;

6) In some cases defined by the Code of Administrative Legal Proceedings of Ukraine to recognize as invalid the court decisions of the court of the first and/or appellate instance in full or partially and to close the case in full or partially in the appropriate part;

7) In some cases defined by the Code of Administrative Legal Proceedings of Ukraine to revoke its resolution (in full or partially) and to take one of the decisions, stipulated by clauses 1-6, part 1, Art. 349 of the Code.

\section{Basic Material of the Study}

Granting a procedural discretion to the Administrative Court of Cassation is explained by consolidation in the Code of Administrative Legal Proceedings of Ukraine of a large number of evaluative concepts such as public-legal relations, violation of rights, freedoms, interests, public-legal disputes, reasonable time, etc. Moreover, these evaluative concepts determine the implementation of justice by the Administrative Court of Cassation under the conditions of a procedural discretion, the further course of the administrative procedure as a whole depends on their interpretation. The category of "administrative case of minor complexity (minor case), in particular, (Article 20, part 1, Article 4 of the CAP of Ukraine) may serve as the evidence of such peculiarities of evaluative concepts.

For the first time in the Code of Administrative Legal Proceedings of Ukraine, the construction of "an administrative case of minor complexity (minor case), enshrined in it, is interpreted in two interrelated ways.

Firstly, in Clause 20, Part 1, Art. 4 of the CAP of Ukraine the very concept of administrative case of minor complexity (minor case) is formulated, with qualifying features of which being recognized as follows: the nature of disputed legal relations, the subject of evidence and 
composition of participants, who do not require the conduct of preparatory proceedings and/or court session for the full and complete establishment of the circumstances of such case. However, in this norm of the Code of Administrative Legal Proceedings of Ukraine, the concept of minor case was formulated by the legislator with the help of evaluative concepts (legal relations, subject of evidence, composition of participants, which do not require the performance of additional procedural actions), which are also perceived ambiguously and require further interpretation.

Secondly, Clauses 1-11, Part 6, Art. 12 of the CAP of Ukraine list the types of cases of minor complexity; to determine them the following is used in the Code:

1) The norms of direct and indirect reference content (Clauses 1, 2, 3, 4, 5, 6, 8, 11, Part 6, Art. 12 of the CAP of Ukraine). For example, the norm of direct reference content is Clause 1, Part 6, Art. 12 of the CAP of Ukraine, as it directly specifies another norm of law to be applied ("admission of citizens to public service, record of service, dismissal from the public service, in addition to cases in which plaintiffs are officials who, in the meaning of the Law of Ukraine "On Prevention of Corruption" occupy a responsible and especially responsible position"). However, the norm of indirect reference content is, for example, Clause 2, Part 6, Art. 12 of the CAP of Ukraine ("appealing against the inaction of the authority or the information manager regarding the consideration of an application or request for information") - there is no indication of the norm of law to be applied, but there are concepts clearly defined by a special regulatory act - the Law of Ukraine "On access to public information";

2) Norms containing evaluative concepts (Clauses 7, 9, 10, Part 6, Art. 12 of the CAP of Ukraine.) For example, "other cases in which the court will conclude that they have minor complexity, except for cases that can not be considered under the rules of simplified proceedings".

It is no doubt that in order to ensure the compliance of the Court decision with the circumstances of the administrative case of minor complexity (minor case), it is necessary to comprehend the constituent parts and determine the peculiarities of the disputed legal relations, to identify and qualify the minor cases features, to evaluate them precisely, to verify the conformity of such an evaluation with the conclusions of the 
local administrative court, the administrative court of appeal, and, finally, to formulate the relevant final objective conclusions.

Therefore, the conclusion on the administrative case of minor complexity (minor case) in accordance with the type and content of disputed legal relations can be made through a systematic system analysis of provisions of the Code of Administrative Legal Proceedings of Ukraine, national administrative law and the scientific interpretation of evaluative concepts.

Thus, according to Clause 8, Part 6, Art. 12 of the CAP of Ukraine, common cases are cases of minor complexity. The concept of a common case is stipulated in Clause 21, Part 1, Art. 4 of the CAP of Ukraine as administrative cases, the defendant of which is the same subject of authority (its individual structural units), the dispute in which arose on similar grounds, in relations governed by the same norms of law and in which the plaintiffs claim about similar requirements.

In order to conclude whether the administrative case has features of a minor complexity case (whether it is minor), it is necessary to evaluate the components and peculiarities of the disputed legal relations and compare it with the features of a minor case at the next stage of the study:

- Disputed relations;

- The subject to be proven;

- The participants of the case and the subject of authority (Clause 7, Part 1 Art. 4 of the CAP of Ukraine);

- The ground for dispute emergence (actual and normative ones);

- The legal norm regulating disputed relations;

- Claim requirements.

The difference between at least one of these components features from the common case makes it impossible to recognize the administrative case as a case of minor complexity (a minor case), and the false equation of the actual disputed legal relations with the normative features of a common case will result in the occurrence of negative procedural outcomes (for example, the refusal to open the proceedings in the pattern case, cancellation of court decisions referring a case to continue consideration or for a new consideration).

The influence of the evaluative concept such as "an administrative case of minor complexity (minor case)" on the procedural discretion of the Administrative Court of Cassation of the Supreme Court as well as the 
consequences of such influence should be studied individually. The court evaluates an administrative case on the subject of its low significance early at the stage of opening of cassation proceedings. The decision on the opening of such proceeding is resulted from various factors including such feature of an administrative case as its low significance.

It should be reminded that the right to the cassation appeal of the court decision can be done only in cases stipulated by law (Clause 8, Art. 129 of the Constitution of Ukraine). Therefore, in the Administrative Court of Cassation the court desicions on cases of minor complexity can not be appealed (Clause 2, Part 5 Art. 328 of the CAP of Ukraine).

The judge of the Administrative Court of Cassation, having received a cassation appeal, has to provide, in particular, a justified response to the following questions:

1) Whether the administrative case appealed, in which a court decision resolution has been approved, is an administrative case of minor complexity (a minor case)?

2) According to the rules of which proceedings (common claim proceedings, simplified claim proceedings) the administrative courts of the first instance, appellate instance have considered the administrative case where the court decision has been approved that is appealed?

3) Are there any grounds for refusal in the opening of cassation proceedings/for the opening of cassation proceedings?

We can see that the evaluative concept of "an administrative case of minor complexity (a minor case)" does not only determine the procedural powers execution at own discretion by the Administrative Court of Cassation - in particular, it can determine the approval for opening or refusing in opening of the cassation proceedings, but it is resulted in further complex branched algorithmic chain of cause and effect links, possible options for resolution of current procedural tasks.

We should analyze the possible conclusions and answers to each of three questions arising in relation to the complaint made to the Court of Cassation.

1. Whether the administrative case appealed, in which a court decision has been approved, is an administrative case of minor complexity (a minor case)?

The answer to this question has already been formulated above and consists in the necessity of evaluating the form and content of the actual 
disputed legal relations and their comparison with the norms of the Code of Administrative Legal Proceedings of Ukraine, establishing the concept of administrative cases of minor complexity (minor cases), the features and types of such cases. The study of disputed legal relations and their verification of compliance with the features of administrative cases of minor complexity (a minor case) provide for the application of such methods of scientific study, such as, in particular, the systemic method, analysis and synthesis. Thus, when evaluating the disputed legal relations, it is necessary to distinguish their subjects, establish the actual and normative grounds for their occurrence and compare them with the norms of the Code of Administrative Legal Proceedings of Ukraine.

2. According to the rules of which proceedings (common claim proceedings, simplified claim proceedings) the administrative courts of the first instance, appellate instance have considered the administrative case where the court resolution has been approved that is appealed?

The answer to this question can be either an opening or a refusal to open a cassation proceeding. It should be reminded that the quality of an administrative case (its low significance, or, conversely, significance), in accordance with the provisions of the Code of Administrative Legal Proceedings of Ukraine, is the basis for opening or refusal to open a cassation proceeding. Thus, court decisions in cases of minor complexity are not appealed under the cassation procedure (clause 2 part 5, Article 328 of the CAP of Ukraine). However, the Administrative Court of Cassation, having received a cassation appeal, at its own discretion differentiates the grounds for opening cassation proceedings in each administrative case.

Therefore, firstly, if the administrative courts of the first, appellate instances (or one of them) considered the administrative case under the rules of the general claim procedure, the Administrative Court of Cassation, having evaluated the actual circumstances of the case and finding that the case should be considered under the rules of simplified proceedings, since, according to the Court conclusions, it is minor, it may be concluded about the refusal to open the cassation proceedings.

Secondly, the Administrative Court of Cassation also evaluates critically the administrative case considered under the rules of simplified proceedings. Cassation proceedings in an administrative case considered 
under the rules of simplified proceedings may be opened for at least two reasons:

- The court of first instance referred the administrative case to the category of cases of minor complexity by mistake (Clause "g", Part 5 of Article 328 of the CAP of Ukraine);

- The Administrative Court of Cassation has reasonable doubts as to the correctness of the definition of an administrative case as minor and it is not possible at the stage of opening the cassation proceedings to conclude whether the administrative case is minor/significant. In connection with these circumstances, there is an objective necessity to open cassation proceedings and investigate the actual circumstances of the administrative case carefully.

Thus, after receiving a cassation appeal, the Administrative Court of Cassation, at its discretion, evaluates the complexity of the administrative case, makes own relevant conclusions regarding its complexity and, as a result, in its own discretion evaluates the possibility of opening a cassation proceeding. The Administrative Court of Cassation is not bound by the conclusions of the Administrative Court of the first instance regarding the low significance or insignificance of the administrative case and determines the quality of a specific administrative case, its low significance/significance independently.

3. Are there any grounds for refusal in the opening of cassation proceedings/ for the opening of cassation proceedings?

In accordance with the general rule stipulated in Clause 8 Art. 129 of the Constitution of Ukraine, the main principles of judicial proceedings are to ensure the right to cassation appeal of a court decision in cases determined by law.

The grounds for refusal to open the cassation proceedings, as we have already mentioned, are stipulated in Clause 2, Part 5, Art. 328 of the CAP of Ukraine: the Administrative Court of Cassation refuses to open cassation proceedings, if the court resolutions are appealed in cases of minor complexity. However, this is not the only reason provided by the Code of Administrative Legal Proceedings of Ukraine. To form a comprehensive conclusion on the existence of grounds for opening a cassation proceedings/refusal to open a cassation proceeding, using the systematic method of study, the provisions of Clause 2, Part 5 of Art. 328 of the CAP of Ukraine should be analyzed also in conjunction with 
clause 20, part 1 of Art. 4, clauses 1-11, part 6 of Art. 12, sub-clauses "a" - "g", clause 2, part 5, Art. 328, part 3, Art. 333 of the Code of Administrative Legal Proceedings of Ukraine.

Studying the norms of the CAP of Ukraine (Clause 20, Part 1, Clauses 1-11, Part 6, Art. 12, Sub-clauses "a"- "g", Clause 2, Part 5, Art. 328, Part 3, Art. 33), we should draw attention to two peculiarities resulted from their analysis:

- The lawmaker in Clause 10, Part 6, Art. 12 of the CAP of Ukraine, using evaluative concepts (such as "other cases in which the court concludes that they are of minor complexity"), has provided the administrative courts with wide freedom to determine administrative cases as cases of minor complexity (minor cases);

- The Sub-clauses "a"-"g”, Clause 2, Part 5, Art. 328 of the CAP of Ukraine provide the evaluative concepts and structures, the existence of which in a particular administrative case "deprives" it of the quality of low significance and, accordingly, binds the Administrative Court of Cassation to open cassation proceedings in an administrative case complicated by such evaluative concepts and structures.

Once again, according to the necessity it is important to evaluate as precisely as possible, whether an administrative case is minor or not, in the event of the party's appeal in the administrative case to the existence of these evaluative concepts and structures, the Administrative Court of Cassation must evaluate and qualify the actual circumstances of the case as accurately as it can and make sure whether there are or there are no such evaluative concepts and structures (Sub-clauses "a" - "g", Clause 2, Part 5, Art. 328 of the CAP of Ukraine):

a) The cassation appeal concerns a right that is fundamental to the formation of a single law enforcement practice;

b) The person submitting the cassation appeal in accordance with this Code is deprived of the opportunity to refute the circumstances established by the appealed court decision in the consideration of another case;

c) The case represents a significant public interest or is of exceptional importance to the party who submits the appeal;

d) The court of the first instance referred the case to the category of cases of minor complexity by mistake. 
It is obvious that the correctness and validity of the administrative case definition as minor on the basis of Clause 10, Part 6, Art. 12 of the CAP of Ukraine, the correctness and validity of the definition of "the issue of law which is fundamental", the deprivation of a person of "the possibility to refute the circumstances", the existence in the case of "significant public interest or exceptional importance of the case", the fact of the mistaken reference of "the cases by the court of the first instance to the category of cases of minor complexity" on the basis of sub-clauses "a" - "g" Clauses 2 Part 5 of Art. 328 of the CAP of Ukraine also influence the opening of cassation proceedings.

We should note that in addition to the criterion of minor complexity (low significance) of an administrative case, the Code of Administrative Legal Proceedings of Ukraine provides for other criteria for verifying the grounds for opening a cassation proceeding/refusal to open a cassation proceeding. All of them are stipulated by Art. 328, 333 of the CAP of Ukraine:

- The fact of the person's participation in the administrative case;

- The fact of resolving the issue on the subjective rights, freedoms, interests and/or responsibilities by the court;

- The type of court decision, which can/can not be appealed under the cassation procedure;

- The grounds for cassation appeal - incorrect application by the court of substantive law norms or violation of procedural law;

- The judicial resolutions in cases of minor complexity;

- An issue of law that is fundamental to the formation of unified law enforcement practice;

- The lack of opportunity to refute the circumstances established by the appealed court resolution in the course of consideration of another case;

- Significant public interest in an administrative case or its exceptional significance for the case participant, who makes a cassation appeal;

- The reference of the case to the category of minor cases by the court of the first instance by mistake.

So, every procedural act, in particular the opening of cassation proceedings, involves not only verification of compliance of administrative case actual circumstances to the norms of the Code of 
Administrative Legal Proceedings of Ukraine, but also proper evaluation of the administrative case qualifying features (actual disputed legal relations, subject of evidence, participants in the disputed legal relations, subject of authority and other subjects, norms of law), factual or procedural circumstances (the case of minor complexity, the question of law, which has a fundamental meaning, significant public interest or exceptional significance of the case, incorrect reference the case to the category of cases of minor complexity by the court of the first instance).

The result of such evaluation will be the choice of a certain type of procedural resolution by the Administrative Court of Cassation from those provided by the Code of Administrative Legal Proceedings of Ukraine. Thus, in the final evaluation of the cassation appeal, the Administrative Court of Cassation may adopt one of the following procedural decisions:

1) To leave a cassation appeal without movement (Part 2, 3, 6, Article 332, Part 1, Article 2, Article 169 of the CAP of Ukraine);

2) To return a cassation appeal to the person who submitted it (parts 5, 6, 7 of Article 332 of the CAP of Ukraine);

3 ) To refuse to open a cassation proceeding (Article 333 of the CAP of Ukraine);

4) To open the cassation proceedings (Article 334 of the CAP of Ukraine).

As we could see, each procedural action (their combination), each stage of the administrative process is covered by a large number of evaluative concepts, which explains the breadth of the procedural discretion of the Administrative Court of Cassation. Accordingly, each type of procedural activity of the Administrative Court of Cassation is characterized by its "own" form of procedural discretion, which requires a thorough scientific studying and uncovering.

After analyzing the norms of the Code of Administrative Legal Proceedings of Ukraine, the criteria stipulated by them for verifying the grounds for opening a cassation proceeding/refusal to open a cassation proceeding, we come to the conclusion on following grounds for refusal to open the cassation proceedings:

- The person did not participate in the administrative case;

- The court did not resolve the issue of subjective rights, freedoms, interests and/or responsibilities; 
- Such court decision is appealed, which according to the rules of the Code of Administrative Legal Proceedings of Ukraine can not be appealed under the cassation procedure;

- The court applied the rules of substantive law correctly or not violated norms of procedural law;

- The court resolutions on cases of minor complexity are appealed, which have been considered under the rules of simplified proceedings;

- The subject of a complaint is a question of law, which is not fundamental to the formation of a uniform law enforcement practice;

- There is a possibility to refute the circumstances established by the appealed court resolution in the consideration of another case;

- An administrative case does not represent a significant public interest or is not of an exceptional significance for the participant in the case who submitted the cassation appeal;

- The court of the first instance referred the case to the category of cases of minor complexity correctly.

However, the absence of these grounds allows the Administrative Court of Cassation to come to the conclusion that the cassation proceedings can be opened. Since there are the criteria for verifying the grounds for opening a cassation proceeding/refusal to open cassation proceeding, the exercise of procedural powers by the Administrative Court of Cassation can not be arbitrary and unreasonable, and the procedural discretion of this Court will have its limits, will be determined by circumstances and be implemented solely under the rules, defined by the Code of Administrative Legal Proceedings of Ukraine.

As it can be seen from the example of the provisions analysis of the Code of Administrative Legal Proceedings of Ukraine on the administrative case of minor complexity (a minor case), the freedom of the Administrative Court of Cassation to exercise its powers is rather significant; instead, the concept, content and peculiarities of procedural discretion have not yet been adequately substantiated by modern administrative procedural science, as it has been not verified by the practice of administrative judicial proceedings.

However, it is obvious that the freedom to exercise the powers of the Administrative Court of Cassation (its procedural discretion) has different types, limits, content of its manifestation. So, procedural discretion has both external and internal differences. 
The procedural (or, as it is also called in the modern literature, judicial) discretion should be distinguished from administrative discretion, since it provides for the powers of a judge to govern the judicial trial (for example, a judge determines certain periods in preparatory proceedings, the specific duties that he will impose on the parties), especially when it comes to finding a court decision (for example, an evaluation of the case urgency or the need for urgent protection of threatened legal benefits in the form of preliminary legal protection). All these cases are covered by the operation of the principle of judge independence and can not be compared with administrative discretion, the use of which is actually verified, although there are certain limits for this, based on the principle of the division of power ${ }^{16}$.

Therefore, from the procedural discretion of the Administrative Court of Cassation, fist of all, should be distinguished its administrative discretion, which to a lesser extent, but still implemented by it. Thus, the Administrative Court of Cassation carries out non-procedural (administrative) powers on the basis of administrative discretion in the event of its entering into administrative-legal relations, arising on the basis of the administrative legislation norms. An example of such legal relations is the legal relations of the public service (admission, passing, termination of the public service), in which the Court is vested, in particular, with the authority to charge and pay monetary support to judges and employees of their staff.

Realizing the existence of the administrative (outside procedural) and procedural discretion of the Administrative Court of Cassation, we should pay attention, firstly, to the fact that it exercises the powers of the administrative court of the first, appeal and cassation instances in accordance with Art. 22, 23, 24 of the Code of Administrative Legal Proceedings of Ukraine.

For example, the Supreme Court (the Administrative Court of Cassation) as a court of the first instance has judicial cases on the establishment by the Central Election Commission of election results or an all-Ukrainian referendum, a case regarding the early termination of the powers of a people's deputy of Ukraine, as well as cases concerning the appeal of acts, actions or inactions of the Verkhovna Rada of Ukraine, the

\footnotetext{
16 Йорг Пуделька 'Понятие усмотрения и разграничение с судебным усмотрением'. Ежегодник публичного права 2017: Усмотрение и оценочные понятия в административном праве. (Инфотропик Медиа 2017) 6, 7.
} 
President of Ukraine, the High Council of Justice, the High Qualifications Commission of Judges of Ukraine, the Qualification-Disciplinary Commission of Prosecutors (Part 4, Art. 22 of the CAP of Ukraine) ${ }^{17}$.

Therefore, we can definitely state that there is a procedural discretion of the Administration Court of Cassation of the following types:

- The procedural discretion of the Administrative Court of Cassation as an administrative court of the first instance;

- The procedural discretion of the Administrative Court of Cassation as an administrative court of appellate instance;

- The procedural discretion of the Administrative Court of Cassation as an administrative court of the cassation instance.

If we evaluate the court proceedings in general regulated by the Code of Administrative Legal Proceedings of Ukraine, it becomes clear that the procedural discretion of the Administrative Court of Cassation as the court of the first, appeal and cassation instances also has a heterogeneous nature. Both the Code of Administrative Legal Proceedings of Ukraine and the practice of administrative judicial proceedings provide for the "consideration and resolution of administrative cases" (for example, Art. 4, 6, 9, 192 and other of the Code). Thus, the task of reviewing the case on the merits is the consideration and resolution of the dispute on the basis of materials collected in the preparatory proceedings, as well as distribution of court costs (Art. 192 of the CAP of Ukraine).

So, secondly, we can see that procedural powers of the Court have a dual orientation:

1) The exercise of procedural rights and obligations regarding the consideration process of administrative cases. For example, the court of cassation instance may consider the case under the procedure of the written proceeding on the materials available in the case in the absence of petitions from all participants in the case on the consideration of the case with their participation (Clause 1, Part 1, Article 245 of the CAP of Ukraine);

2) The exercise of procedural rights and obligations for the resolution of an administrative case (cassation appeal) on the merits (the discretion to resolve an administrative case on the merits).

In the Administrative Court of Cassation procedural powers may be exercised by the various compositions (organizational and procedural

\footnotetext{
${ }^{17}$ Кодекс адміністративного судочинства України: Закон України від 06.07.05 р. № 2747-IV (в редакції Закону України від 03.10.17 р. № 2147-VIII). Відомості Верховної Ради України. 2017. № 48. С. 5.
} 
forms) of this Court: a judge individually, a panel of judges, a chamber, a unified chamber. For example, a cassation appeal is not taken for consideration and returned by the reporting judge if it is submitted by a person who has no administrative procedural capacity, not signed or signed by a person who is not entitled to sign it, or by a person whose position is not indicated (Clause 1 Part 5 Art. 332 of the CAP of Ukraine). The court hearing the case under the cassation procedure in the panel of judges, chambers or unified chambers shall transfer the case to the Grand Chamber of the Supreme Court if such a panel (chamber, the united chamber) considers it necessary to deviate from the conclusion on the application of the law norm in such legal relations, stipulated in the previously adopted resolution of the Grand Chamber (Part 4, Art. 346 of the CAP of Ukraine $)^{18}$. In the same way, there is a procedural discretion of the judge, the panel of judges, the chamber, and the unified chamber of the Administrative Court of Cassation.

The division of the Court discretion under the conditions, in which it functions, depends on various numerous criteria:

- The stages of the administrative procedure;

- The forms of administrative judicial procedure - general claim proceeding, simplified claim proceeding (Art. 12 of the CAP of Ukraine);

- The administrative procedure participant (Art. $42-71$ of the CAP of Ukraine);

- The composition of the Administrative Court of Cassation of the Supreme Court (Art. 31-33 of the CAP or Ukraine);

- The type of procedural action, inaction or other external manifestation (form) of execution of procedural powers;

- The norms (order, provision) of the Code of Administrative Judicial Procedure of Ukraine; Rights;

- National judicial practice, practice of European Court on Human

- The type of decision, action, inaction or any other external manifestation of the power execution of subject of authorities;

- Any external manifestation of execution of powers of physical person, legal entity;

- The subject of administrative-legal relations (for example, public property or other object of real estate).

\footnotetext{
${ }^{18}$ Кодекс адміністративного судочинства України: Закон України від 06.07.05 р. № 2747-IV (в редакції Закону України від 03.10.17 р. № 2147-VIII). Відомості Верховної Ради України. 2017. № 48. С. 5.
} 
Therefore, the procedural discretion of the Administrative Court of Cassation of the Supreme Court is a peculiar "winding broken line" of (a set of) procedural actions, determined by actual circumstances, requirements and provisions of law, which (procedural actions) finally lead to the adoption of a court resolution.

Taking into account and under the influence of these criteria, the Court, accordingly, carries out justice in a variety of different ways of the procedural discretion. At the same time, these types of procedural discretion are inseparable from each other in time, since when considering and resolving an administrative case the Administrative Court of Cassation constantly chooses between the varieties of its procedural discretion. As a rule, there are no difficulties with the definition of a particular type of discretion in the Court. However, the problem is in other thing: to determine which of the possible resolutions should be chosen by the Court, taking into account the existing circumstances. A significant challenge to the Court is to perform actions in the following sequence:

- To collect information about all facts and circumstances which are of fundamental importance for the correct resolution of an administrative case;

- To evaluate this information objectively and compare it with the relevant rules of substantive law;

- To correlate the actual circumstances, the requirements of the legislation with procedural powers, vested on the Administrative Court of Cassation;

- To correlate the conclusions obtained in the end of such evaluation, the powers of the Court with the norm (norms) of the Administrative Code of Judicial Procedure of Ukraine as closely as possible, which were previously selected for use in relation to the conclusions;

- To state in the relevant court decision the results obtained after comparison and generalization.

Each type of procedural discretion of the Administrative Court of Cassation corresponds to the "own" set of criteria (conditions) required for consideration when choosing and adopting procedural resolutions. For example, a person who did not take part in a case, if the court decided on their rights, freedoms, interests and/or responsibilities, has the right to file a cassation appeal only after reconsidering under the appeal procedure according to person's appeal (Part 5, Art. 328 of the CAP of Ukraine). Having analyzed this norm, it becomes obvious that the Administrative Court of Cassation, evaluating the grounds for opening a cassation 
proceeding on a complaint from a person who has not participated in the case, would check the fact of resolving the issue on the rights of the plaintiff by the administrative court.

As a result of procedural rights execution by the Administrative Court of Cassation, the evaluation of actual circumstances and the norms of law, it approves procedural resolutions, which, depending on certain criteria (circumstances), can be differentiated into types:

- The current procedural decision (court decision) approved in connection with the process of consideration of the cassation appeal. Procedural issues related to the movement of the case, the petitions and statements of the participants in the case, the issues on postponing the case consideration, the announcement of a break, the suspension of proceedings, as well as in other cases provided for by the Administrative Code of Legal Proceedings of Ukraine, are decided by the court of cassation instance by court decisions under the procedure established by the Administrative Code of Legal Proceedings of Ukraine for the adoption of decisions of the court of the first instance (Part 2, Art. 355, Art. 241 of the CAP of Ukraine);

- The final procedural decision, adopted on the results of consideration of the cassation appeal (administrative case). The court of cassation instance, on the basis of the results of consideration of the cassation appeal adopted the court resolutions in the form of decree in accordance with the requirements established by Art. 34 and Chapter 9 of section II of the Code of Administrative Legal Proceedings of Ukraine (Part 1, Art. 355 of the CAP of Ukraine).

Therefore, we have to agree that the main problems of the judge and the judicial procedure arise not in connection with the formal correlation of preconditions and conclusions, legal features of the situation and its legal consequences, that is, not in relation to legal syllogism. A much more complex task of judicial procedure and jurisprudence in general is the search, establishment and distinguishing of legally significant features. First of all, we speak about the features of the very law norm that will regulate the situation, and the features of a particular situation, that is, a certain case of life, which actually requires a legal solution. So, R. Cippelius comes to the conclusion that the resolution of legal cases (for example, regarding how many parties owe one another under the agreement, or whether an employee can claim damages resulting from labor injuries, etc.) is a complex lace. It is made out of finding prerequisites, their accurate outlining; establishing which of the norms 
should be applied. Finally, the actual implementation of the norm takes place, that is, the use of the legal consequence as a logical conclusion resulted from the establishment of prerequisites and determines the proper conduct $^{19}$.

As the practice of administrative judicial procedure shows, it is not enough to find, establish and distinguish the legally meaningful features of the law norm regulating a certain situation ${ }^{20}$. At the discretion of the Administrative Court of Cassation and the adoption of the final procedural resolution will influence how the Court will evaluate and interpret the actual circumstances in relation to the specific norm of substantive law.

Thus, a court resolution may be canceled in whole or in part and instead a new resolution is made or it is changed in the appropriate part due to the incorrect application of the substantive law norms. Incorrect application of the substantive law norms is a misinterpretation of the law or the application of law that should not be applied or the non-application of the law that would have been applied (Part 1, 3, Art. 351 of the CAP of Ukraine) $)^{21}$.

Therefore, for the adoption of a legitimate and justified court resolution on the basis of procedural discretion of a certain type, it is necessary to form a comprehensive list of criteria, the combination and content of which will determine the type of court resolution that will most fully correspond to the actual circumstances.

\section{CONCLUSIONS}

Therefore, the "own" list of criteria corresponds to each type of procedural discretion of the Administrative Court of Cassation. When examining the actual circumstances, interpreting them and relevant substantive legal norms, drawing conclusions on the correspondence of actual circumstances to the law norms, the Court examines them for compliance with the criteria from the list for a certain type of procedural discretion. Of course, it is not easy to make a comprehensive list and to describe the criteria of the procedural discretion of the Administrative Court of Cassation in a certain case, since the actual circumstances of the

\footnotetext{
${ }^{19}$ Райнгольд Циппеліус Методика правозастосування (Юстініан 2016) 141.

${ }^{20}$ Райнгольд Циппеліус Методика правозастосування (Юстініан 2016) 141.

21 Кодекс адміністративного судочинства України: Закон України від 06.07.05 p. № 2747-IV (в редакції Закону України від 03.10.17 р. № 2147-VIII). Відомості Верховної Ради України. 2017. № 48. С. 5 .
} 
case are ambiguous, it is rather difficult to evaluate them, interpret and compare with the substantiate law norms.

Each criterion of procedural discretion of a certain type is evaluated both individually and in interrelation and in combination with other criteria; their relations and meaning for the final procedural resolution is evaluated. So, can we consider the refusal to open proceedings in an administrative case as reasonable (closing proceedings in an administrative case in the appropriate part based on the grounds stipulated, respectively, by Art. 238, 240 of CAP of Ukraine) (Art. 170, 238, 354 of CAP of Ukraine)?

For example, in relation to the dismissal of an administrative complaint by the national administrative courts (submitted in accordance with Art. 2 and Art. 4 of the Code of Administrative Legal Proceedings of Ukraine $)^{22}$ on the arbitrary search by the police of a private home and the payment of moral damage for violation of the home integrity, the European Court of Human Rights in the case "Kuzmenko against Ukraine" explained that, taking into account the fact that national courts refused to consider the applicant's complaint, referring him to the procedure that was neither accessible nor capable of bringing to the immediate and prompt settlement of his civil claim, the applicant was denied in the right to access to the court in the very essence. There was respectively a violation of Clause 1 of Art. 6 of the Convention ${ }^{23}$.

Based on the results of the study described above, the procedural discretion of the Administrative Court of Cassation of the Supreme Court can be defined as the freedom of choice by the Administrative Court of Cassation (administrative court) of one or more procedural resolutions as defined by actual circumstances, norms of law and judicial practice from those provided by the norms of the Code of Administrative Legal Proceedings.

The practice of administrative judicial proceedings objectively requires not only justification of the types of procedural discretion of the Administrative Court of Cassation, but also a comprehensive description of possible algorithms of its procedural actions during the cassation reconsideration of administrative court resolutions of the first and appellate instances and the implementation by the Administrative Court of Cassation of other procedural powers.

\footnotetext{
${ }^{22}$ Кодекс адміністративного судочинства України у редакції до 15 грудня 2017 р. (npuм. aвm.).

23 Справа «Кузьменко проти України» (заява № 49526/07). Рішення від 9 березня 2017 р. [Електронний ресурс] - Режим доступу: http://hudoc.echr.coe.int/eng?i=001-171782
} 
The distinction and justification of the procedural discretion types of the Administrative Court of Cassation (administrative court) and its meaning in relation to certain, specific categories of administrative cases is urgent and practical.

\section{SUMMARY}

To ensure the fulfillment of the task of administrative judicial procedure, its "flexibility", the fullest protection and renewal of rights, freedoms, interests of physical persons (legal entities), the effective exercise of procedural functions, the administrative courts, as well as the Administrative Court of Cassation of the Supreme Court, have procedural powers that they realize at their own discretion. At the same time, the procedural discretion of the Administrative Court of Cassation of the Supreme Court can not be unlimited, arbitrary. The above mentioned discretion (freedom of actions) is determined by the actual circumstances, the requirements of legislation, judicial practice, and practice of the European Court on Human Rights.

It should be noted that the necessity for a justified choice is objectively inherent in the whole process of reviewing and resolving an administrative case or procedural actions associated with it.

The "own" list of criteria conforms to each type of procedural discretion of the Administrative Court of Cassation. When examining the actual circumstances, interpreting them and corresponding substantive law, drawing conclusions on the correspondence of actual circumstances to the law norms, the Court examines them for compliance with the criteria from the list for a certain type of procedural discretion. Definitely, it is not easy to make a comprehensive list and describe the criteria of procedural discretion of the Administrative Court of Cassation in a particular administrative case, since actual circumstances are quite often ambiguous; it is rather difficult to evaluate, interpret and compare them with the substantive law norms.

\section{REFERENCES}

1. Кодекс адміністративного судочинства України від 6 липня 2005 р. № 2747-IV (в редакції Закону України від 3 жовтня 2017 р. № 2147-VIII) // Відомості Верховної Ради України. - 2017. - № 48. C. 5 .

2. Головатий С. Верховенство права (правовладдя): як його тлумачить Венеційська Комісія / Верховенство права: доповідь, 
схвалена Венеційською Комісією на 86-му пленарному засіданні (Венеція, 25-26 березня 2011 року) // Право України. - 2011.№ 10 . - C. 168-184.

3. Report on the Rule of Law. Adopted by the Venice Commission at its 86th plenary session (Venice, 25-26 March 2001) on the basis of comments by Mr Pieter van Dijk (Member, Netherlands), Ms Gret Haller (Member, Switzerland), Mr Jeffrey Jowell (Member, United Kingdom), $\mathrm{Mr}$ Kaarlo Tuori (Member, Finland). Study No. 512/2009. CDL\#AD(2011)003rev. Or. Engl.

4. Адміністративне право і процес УНР в екзилі: невідома правнича спадщина України / Укладачі: I.C. Гриценко, В.М. Бевзенко, С.О. Коваль, А.І. Бевз, І.В. Паламарчук, О.В. Гура, А.В. Кравченко, Р.С. Сметанюк; за заг. ред. І.С. Гриценка. - К.: Дакор, 2015. - 500 c.

5. Friedhelm Hufen Verwaltungsprozessrecht. 7., vollig neu bearbeitete Auflage. Verlag C.H. Beck München, 2008. - 642 s.

6. Наука адміністрації й адміністративного права. Загальна частина (за викладами професора Юрія Панейка) / Укладачі: В.М. Бевзенко, І.Б.Коліушко, О.Р. Радишевська, І.С. Гриценко, П.Б. Стецюк. - К.: Дакор, 2016. - 464 с.

7. Пуделька Й. Понятие усмотрения и разграничение с судебным усмотрением // Ежегодник публичного права 2017: Усмотрение и оценочные понятия в административном праве.- М.: Инфотропик Медиа, 2017. - 480 с.

8. Циппеліус Р. Методика правозастосування. - К.: Юстініан, 2016. - $191 \mathrm{c}$.

9. Справа «Кузьменко проти України» (заява № 49526/07). Рішення від 9 березня 2017 р. [Електронний ресурс]- Режим доступу: http://hudoc.echr.coe.int/eng?i=001-171782

Information about the author: Bevzenko V. M. Doctor of Law, Professor at the Department of Administrative Law, Judge of Administrative Court of Cassation of the Supreme Court of Ukraine 